\title{
The Power of Politeness Strategies in EFL Student-Teacher Interaction: Teacher's Gender Perspective
}

\author{
Riyan Febriansyah, riyan19017@mhs.unesa.ac.id, Universitas Negeri Surabaya, \\ Surabaya, Indonesia \\ Ahmad Munir, ahmadmunir@unesa.ac.id, Universitas Negeri Surabaya, Surabaya, \\ Indonesia \\ Syafi’ul Anam, syafiulanam@unesa.ac.id, Universitas Negeri Surabaya, Surabaya, \\ Indonesia \\ Slamet Setiawan, slametsetiawan@unesa.ac.id, Universitas Negeri Surabaya, Surabaya, \\ Indonesia
}

\begin{abstract}
This study was aimed to investigate the use of politeness strategies in male and female teachers' classrooms. Since the nature of student-teacher interaction was often influenced by the teachers' actions and utterances, it was necessary to investigate the politeness based on the teachers' gender perspectives, where those interactions sometime could be felt like either threatening or enjoyable. Investigating how male and female teachers' politeness resulted in enjoyable student-teacher interaction differently, to empower the EFL classroom, this study also elaborated how the power of politeness strategies maximize the EFL student-teacher interaction. The participants are several teachers and students who conduct the English Intensive Course Program in an undergraduate university, where they interacted using English during the classes. In addition, this research followed qualitative research design and used observation to collect data. Applying Brown and Levinson's theory of politeness, the results show that politeness strategies bring a lively and friendly atmosphere during the classroom interaction. Specifically for female teachers who mostly use positive politeness strategy, they build more interaction with the student rather male teachers. Positive politeness strategy focused on the students' positive face by expressing the number of utterances that want to be listened to by the students. It keeps students to have willingness to communicate so that the student-teacher interaction in EFL classroom can be maximized.
\end{abstract}

Keywords: English language teaching; politeness strategy; teachers' gender; teacher's utterances; student-teacher interaction

\section{INTRODUCTION}

The way teachers engage with their pupils has a significant impact on the social distance between them. Different responses from pupils may be elicited by various instructor statements. As a result, in order to avoid negative responses from students, instructors employ a variety of methods during the teaching and learning process in order to foster student-teacher engagement. Because it's critical to establish a teacher's actions and expressions during the teaching and learning process, demonstrating politeness is one of the ways a teacher may assist sustain the student-teacher relationship. 
People from a wide range of languages and cultures use politeness as a common phrase. This term is commonly used to avoid face-threatening actions between individuals (the speaker and the listener), particularly during conversation (Brown \& Levinson, 1987). In a discussion, expressing some civility will improve the comfort level between the speaker and the listener (Mahmud, 2019). Brown et al. (1987) simplified politeness into key qualities since there are many different ways to exhibit politeness. It is now referred to as the politeness strategy. According to Aulia (2017), studying politeness strategy entails learning how individuals utilize certain languages during communication with the goal of facilitating smooth and good interactions. Politeness is defined as a concept established by human societies to reduce friction in communication, the way individuals avoid disputes during communication, or simply the strategic conflict avoidance in any discussion setting. (Eelen, 2008; Kasper, 2005; Lakoff \& Ide, 2005; Leech, 1983; Lakoff \& Ide, 2005; Leech, 1983).

Because there is a lot of dialogue in the contact between instructor and student, the researchers incorporate the politeness approach into the teaching and learning process. Jiang (2010), citing a prior research, claimed that, like other discussions, student-teacher dialogues have the potential to harm the listener's face. In the framework of the teaching process, the teacher's words are a critical component that has a significant impact on the students' replies. When students react adversely to their instructor, the classroom becomes uncomfortable and less communicative. There will be a break in student-teacher interaction as a result of this. As a result, the researchers explore the power of the teacher-led politeness technique in EFL student-teacher interactions by asking instructors to use it in their classrooms.

Sulu (2015) investigated many aspects of the English language teaching process and discovered that the instructor frequently used the politeness approach. Its benefits include improving the quality of student-teacher interaction. Previous research has indicated that classroom civility tactics improve learning by creating a dynamic and pleasant environment.

In another study, Liu Peng et al. (2012) found that instructors commonly employ politeness techniques. They claimed that a teacher's civility technique is crucial in the classroom. The instructors use the civility technique in their classroom in a realistic way. The instructor, on the other hand, generally shows courtesy in a direct manner. A similar finding from another study, Hanik et al. (2019), revealed that most instructors prefer to demonstrate courtesy in a direct manner. Unfortunately, just a few research have looked into politeness expression from the standpoint of instructors' gender. There's still a chance that a teacher prefers to use the politeness expression indirectly, or that a different instructor's gender uses a different politeness expression often.

The researchers undertake a deeper investigation into the power of a teacher's politeness technique in EFL student-teacher interaction by looking at the teacher's gender as well. Because the expression of politeness is mostly determined by gender differences, it is also necessary to consider the teacher's gender while employing politeness strategies. Makarova and Pourmohammadi (2019) found that politeness is expressed differently by men and women in numerous cultures. In New Zealand, for example, women are said to offer and get more compliments than males. Coates (2004) also discovered that males swear more more than women in the United States and the United Kingdom.

There are also certain difficulties connected to instructor gender disparities in the teaching and learning process. Rajesh and Udgaonkar (2018) performed a study that looked at the gender of teachers. They discovered that pupils feel more at ease when they are taught by a female rather than a male instructor in a secondary school setting. According to Eliasoph (2003), men and women exhibit distinct levels of verbal politeness. Female speech is considered to be more polite than male speech when considering conversational standards. Students favored girls because they believed it was easier to interact with them, according to the survey. Females, according to the kids, are caring, industrious, and have an audible high-pitched voice. Female instructors are viewed as more successful teachers by kids due to their demeanor and approach, which is gentler, understanding, and kind.

127 | IJET| Volume. 10, Issue 2. December 2021 Copyright 2021 Riyan Febriansyah, Ahmad Munir, Syafi'ul Anam, and Slamet Setiawan are licensed under Creative Commons Atrribution-ShareAlike 4.0 International License. 
Several researches have clarified the concept of politeness (Boufranch \& Conejos, 2003; Brown \& Levinson, 1987; Lakoff \& Ide, 2005; Leech, 1983; Watts, 2003). The basic notion of civility is enlightened by these academics. Every participant in a communication exchange is endowed with a feature known as a face. It is a description of one's self-image in the context of social relationships (Leech, 1983). In addition, the face represents honor, self-esteem, and public image. We must protect other people's faces because we do not want our own to be endangered. As a result, courtesy expressions are frequently employed during conversation to avoid face-threatening acts.

The speaker is most likely threatening the hearer's face, based on the conversational setting. The speaker is the one who makes the utterances, whereas the hearer is the person who listens to them (Murphey, 2001). When the hearers have previously been threatened, it is assumed that they have been subjected to Face Threatening Acts (FTA). These are the actions taken by the speaker to put the listener in danger (conscious or unconsciously). It is an act in which the speaker tends to speak in ways that are at odds with the hearer's face desires in a conversation, either to threaten positive or negative face desires (Jane 1989). The term "politeness techniques" refers to verbal messaging strategies that satisfy the listener's facial expression. It's a tactic employed to keep the hearer's face from being harmed. Speakers typically employ politeness tactics to avoid or at least reduce the risk of the Face Threatening Act (FTA) (Ryabova, 2015).

Many linguists believe that politeness techniques are important in preserving social order and regard it as a prerequisite for human collaboration. According to Lakoff and Ide (2005), the goal of employing politeness tactics is to prevent confrontation. These tactics had been practiced from the time of the children. For instance, when a mother instructs her children to welcome their neighbors or when they are required to thank someone who provides them with sweets. It appears that adhering to these standards, which have been learned since the beginning of time, is critical. According to Brown and Levinson (1987), there are four politeness techniques.

The most straightforward technique is known to be bald on record politeness. This method employs the urgent form of utterances and is used when there is just a minor threat to one's face. This approach is most commonly used with listeners who are close and comfortable with one other, such as friends and family members. The bald on record strategy is the polar opposite of the off record technique. This technique requires the speaker to express themselves more. People who utilize off-the-record frequently express themselves in a hazy, vague, and oblique manner. Negative politeness is a method for demonstrating social distance between the speaker and the listener. Negative politeness is a tactic for avoiding confrontation. Negative politeness suggests that speakers respect the addressee of the hearer's negative face and does not obstruct the hearer's ability to behave freely. The sensation of sadness or a smile-down face is associated with the negative face, whereas the feeling of happiness or a smile-up face is associated with the positive face. The opposite of negative politeness approach is positive politeness strategy. Positive politeness creates a sense of familiarity in others. It's also known as the language of intimacy. The goal of positive politeness is to turn any frightening conduct into a pleasant face. This technique also makes the listener feel that he or she is a member of a group, such as friends or relatives.

As a result, not only is the strength of a teacher's politeness approach in EFL studentteacher interaction being investigated, but also the relevant study literatures on the issue of politeness strategy are being filled. However, when male and female teachers utilize particular civility tactics during the teaching and learning process, they are compared. To sum up the whole explanation of the study's background and stay focused on the research goals, the researcher provides a research problem as below. How do different gender teachers empower politeness strategies in student-teacher interaction? The following research questions, then, were posed following the statement of research problem in this study: (1) What politeness strategies are frequently used by male and female teachers in powering EFL student-teacher 
interaction? (2) How does the power of politeness strategies run the EFL student-teacher interaction?

\section{METHOD}

This research was conducted in an Indonesian undergraduate university's English Foreign Language (EFL) classroom. It is concerned with the distinction between male and female teachers while using specific etiquette tactics. Furthermore, this research looks into how male and female teachers employ politeness tactics to influence student-teacher interactions. Students and teachers from the English Intensive Course Program in the second semester of school are among the participants. The research comprised 30 students and two professors (one male and one female). The researchers utilized observation to obtain data and used a qualitative study methodology. The importance of observation and recording in expanding the conversation and determining the outcome cannot be overstated. Because we cannot separate what people say from the environment in which they say it, whether this context is their education, belief, or experience, qualitative research was utilized to understand the contexts or settings in which participants in a study address a problem or topic (Creswell, 2007).

Moreover, the pragmatic analysis was applied in the research. the pragmatic approach to science involves using the method which appears best suited to the research problem and not getting caught up in philosophical debates about which is the best approach (Davies \& Elder, 2004). Therefore, a pragmatic researcher will be able to grant himself the freedom to use any of the methods, techniques and procedures typically associated with quantitative or qualitative research. Maxcy \& Spencer (2003) also stated the pragmatic approaches may use different techniques at the same time or one after the other.

Based on Jiang's findings, the researchers focused on the teacher's utterances (activity) and student's attitude (response) in four teaching-learning process categories when assessing the teacher's politeness approach. Based on the students' reactions to the teacher's words, the way politeness technique develops student-teacher interaction was demonstrated. According to Aulia (2017), when the instructor uses more courteous utterances, kids have a better attitude. The data for addressing the study questions comes from the students' attitudes while the instructor teaches utilizing the politeness method.

The observation of the teaching process is based on Jiang's four categories (2010). According to Jiang's research, student-teacher contact occurs more frequently during specific instructional activities. According to Jiang (2010), there are four teaching process areas in which the teachers speak affects the students' attitude toward their instructor. Instruction, motivation, evaluation, and classroom management are the four areas. It includes all of the teacher's utterances in directing students' learning activities, such as guiding students' classroom presentations, replying to students' questions, and providing corrective feedback in academic teaching. Motivation entails illocutionary activities aimed at encouraging students to ask questions, participate in discussions, and provide feedback to their peers. When it comes to how the instructor evaluates the pupils, there are two key aspects to consider. Furthermore, the teacher's words may both motivate and discourage the students. While classroom management encompasses a variety of scenarios including instructions, directives (orders, requests, inquiries, and calls), procedural direction, and procedural directives, it also includes procedural direction and procedural directives.

As a result, it was able to determine which of the instructor's politeness strategies developed the relationship between teacher and students based on the students' attitude when replying to the teacher. The researcher, on the other hand, looked into all of the teacher's comments based on the four teaching process categories. Based on Brown and Levinson's politeness theory, the statements were divided into four types. Their utterances were also

129 | IJET| Volume. 10, Issue 2. December 2021

Copyright 2021 Riyan Febriansyah, Ahmad Munir, Syafi'ul Anam, and Slamet Setiawan are licensed under Creative Commons Atrribution-ShareAlike 4.0 International License. 
separated into two parts depending on genders to compare the usage of politeness techniques among male and female professors.

\section{RESULTS}

\section{Kinds of politeness strategies used by male and female teachers}

This research enlightened that both male and female teachers use politeness strategies in their utterances. Specifically, this research reveals what politeness strategies that mostly used by the teachers, and when the teachers use politeness to maximize the classroom interaction. According to the data, politeness strategies have been found when the teachers instruct, motivate, evaluate, and manage the classroom. No exception, those four teaching process categories are involved by politeness strategies. There was no teaching categories escaped from the utterances of politeness strategies.

Teachers' politeness strategies that uttered in order to instruct the classroom are mostly in the form of bald on record politeness strategy. Identifying the utterances based on Brown and Levinson's theory, it was a part of bald on record strategy. The utterances are categorized as bald on record strategies, since it headed for uttering polite expression in a direct way. A direct statement means that the speakers prefer to say what they want to say, without involving any ambiguity. An indication of saying direct statements is the use of interrogative sentences. In these classrooms, teachers mostly involved the interrogative utterances with certain polite words such as saying the students' name, calling them honey or beloved, etc. After getting several statements, students' responds are positively raised. They have more willingness to communicate since they have to answer teacher's instructions. The examples of utterances were as below

Class leader, would you like to lead the pray first please?

Is there your beloved friend who doesn't come to the class?

Put you smile up and Please listen, let us begin the absent

Before starting the class, better for our successfulness to pray at first.

Meanwhile when motivating, evaluating, and managing the classroom, the researchers also found a lot of teachers' politeness strategies. In motivating the classroom, teacher usually conduct off record and positive politeness strategies. The statements are used to motivate the students in order to burn their enthusiasm to study. Motivating is an act of politeness. It also can be a way to make students' willingness communicate. Since motivating is uttered excessively with the long sentences, it then categorized as the off record politeness strategies The utterances were recorded as below.

Do not give up on your education. I faced similar challenges as a student many years ago. But I..

I know you've been listening to me since the beginning of class, and you students are an excellent example of..

Don't be frightened; take a deep breath and relax. I'll assist you in responding to the audience's query.

Before starting the class, better for our successfulness to pray at first.

In evaluating the classroom, teachers utter a statement that closed to positive politeness strategy. The statements were a part of positive politeness strategy since it shares the feeling of familiarity among student and teacher. Its goal is to transform any dangerous behavior into a

130 | IJET| Volume. 10, Issue 2. December 2021 Copyright 2021 Riyan Febriansyah, Ahmad Munir, Syafi'ul Anam, and Slamet Setiawan are licensed under Creative Commons Atrribution-ShareAlike 4.0 International License. 
good image. The remarks treated the hearer as though they were a member of a group, such as friends or family, as a positive politeness technique. Positive politeness is used to reduce the social gap between the speaker and the listener by expressing warmth. This technique is distinguished by the speaker's tendency to indicate the number of utterances that the listener wants to hear. The examples were below.

\section{You kids did a fantastic job today! You all raised a perfect job.}

Meanwhile to manage the classroom teachers tend to apply several politeness strategies including bald on record, off record, and positive politeness strategies. Teachers' statements were transcribed as below.

Those three good boys come on, please move in front here.

Don't be noisy dear please; Listen up, follow the instruction and let us practice.

Students, I would be very happy if you be quieter.

Looking at the pattern of teachers' utterances, in academic teaching parts, teachers tend to exhibit courtesy more. The term "academic instruction" refers to a teacher's direction of a student's learning activity or academic presentation. It addresses how the instructor responds to the students' questions as well as how the teacher provides corrective feedback. For example, when a teacher enters the classroom and begins teaching, the instructor's role in leading the pupils is referred to as academic instruction.

Since it is proven that a lot of politeness strategies applied by the teachers, the researchers are easier to investigate what kinds of politeness strategies that frequently used by male and female teachers in empowering EFL student-teacher interaction. The result show both male and female teacher mostly use on record, off record, and positive politeness strategies.

The findings indicated a comparison of politeness strategies employed by male and female professors, with the high frequency of politeness expressions being nearly same. However, research appears that female teachers employ more civility tactics than male teachers during the teaching and learning process. However, a closer examination of the data reveals that male and female teachers have distinct preferences for utilizing politeness strategies. Female teachers are more likely to use positive politeness tactics, whereas male teachers are more likely to use on-the-record politeness strategies.

Based on Brown and Levinson's hypothesis, the researchers looked into instructor utterances and classified them into four types of politeness strategies (1987). The bald on record, off record, positive politeness, and negative politeness techniques are the four politeness strategies. According to research on male teachers, the most common approach is to go bald on record. Positive civility and an off-the-record technique follow. When compared to the female instructor, there are just a few bald-related remarks on record. Positive civility is preferred by female teachers. Positive politeness is used in almost every female teacher's statement.

When the researchers looked at the data, they discovered that no teachers utilized a negative politeness technique. Negative politeness is counted as zero in both male and female teacher statistics. The researchers give a quick table as well as a more detailed explanation of male and female instructors' civility tactics below.

\section{a. Male teacher's politeness strategy}

Jiang gathered data on instructors' politeness tactics from their utterances through the four categories of the teaching process (2010). The researchers delve deeper into some important lines in this part to present a clear research result on male and female instructors' civility methods. 
The discussion are divided into two section based on the teacher's gender. Following the data, the male teacher states a less utterances using politeness strategy compared to the female teacher. More specific, the male teacher applied bald on record, off record, and positive politeness strategy. Although there are three types of politeness strategies that used certainly, the result shows that male teacher prefers to use bald on record rather than the three other strategies.

Talking about bald on record specifically when this strategy is conducted, the teachers indicated they want to be fast in finishing teaching process. Through the observation data, it showed the teaching and learning process finished no more than the scheduled time. All closing activities is even ended a little bit earlier. So that the classroom finished early.

When discussing how the bare on record method runs the student-teacher relationship, it is well known that students dislike teachers who frequently undertake the instructional process outside of the allotted time. Because the classroom is done quicker, the instructor may encourage pupils to just listen and focus during the teaching process without regard for the amount of time allotted. Although it may improve students' attitudes, it is difficult to increase student-teacher contact in certain classroom situations. Furthermore, as compared to studentteacher interactions with female teachers, pupils who are taught by male teachers are less talkative.

\section{b. Female teacher's politeness strategy}

In the other hand, data on the female teacher showed that the females uttered a lot of politeness strategy compared to the males. More specific, the female teacher applied bald on record, off record, and positive politeness strategy. But different with the male teacher, the result shows that female teacher prefers to use positive politeness rather than bald on record strategy during the teaching and learning process.

Positive politeness is the most appropriate technique for maximizing student-teacher engagement, as evidenced by the prior discussion. A female teacher's ability to establish greater engagement with her pupils is explored using the power of positive politeness method. This occurs because female teachers employ a more positive politeness technique than male teachers, who prefer a bald on record approach. Positive politeness approach utterances are defined as utterances that encourage students to communicate more during the teaching and learning process.

Despite the fact that data on teachers' politeness methods varies, a fact revealed that neither male nor female instructors utilize negative politeness strategies. The use of negative politeness is counted as zero in both male and female instructors' data. This technique is actually based on avoidance. Negative politeness encourages speakers to respect the addressee of the hearer's negative expression and does not obstruct the hearer's freedom of action (Brown \& Levinson, 1987). Teachers do not utilize the negative politeness technique, presumably because it is the polar opposite of positive politeness. This method fails to recognize the importance of solidarity. When using a negative politeness technique, it is immediately assumed that there is some social gap between the student and the teacher. However, because the researchers did not conduct any interviews, it is still unclear why teachers avoid using negative politeness strategies. To finish the more comprehensive research on the concerns of instructors' politeness tactics, additional preparation and inquiry are required.

\section{Politeness strategy in empowering EFL student-teacher interaction}

Since there were a lot of polite communication happen among the classroom agents during the teaching and learning process, it is indicated that politeness strategies take a role in building the interaction among teacher and student through its polite expressions. So that, here

132 | IJET| Volume. 10, Issue 2. December 2021

Copyright 2021 Riyan Febriansyah, Ahmad Munir, Syafi'ul Anam, and Slamet Setiawan are licensed under Creative Commons Atrribution-ShareAlike 4.0 International License. 
the researchers elaborate how the power of politeness strategies run the EFL student-teacher interaction.

When pupils are threatened more nicely, they are more likely to have a good attitude toward the instructor. According to Aulia (2017), children become more communicative when the instructor expresses specific utterances that students want to hear, such as praising, joking, and so on. When comparing Aulia's remark to the four types of politeness techniques, it appears that positive politeness is the best strategy for improving student-teacher relationship.

One of the characteristics of positive politeness approach is choosing an expression depending on the expectancy of the listener. This technique allows the speaker and the listener to share a sense of familiarity. The instructor strives to create a sense of home in the classroom by employing positive politeness in the context of English language education. The goal of positive politeness is to turn any frightening conduct into a pleasant face. This technique also makes pupils feel like they are a member of a group, such as friends or family. Positive politeness aims to build a sense of unity between the speaker and the hearer; or teacher and student, by selecting the utterances that wish to be heard by the hearer. Brown and Levinson (1987) go on to explain how to pay attention to the listener (his interests, wants, needs, and goods); exaggerate (interest, approval, sympathy with the listener); intensify (interest, approval, sympathy with the hearer); seek agreement; joke; offer and promise; be optimistic; and give gifts to the listener (goods, sympathy, understanding, cooperation).

The findings of this study, which confirm the findings of Aulia (2017), show that positive politeness strategies increase student-teacher engagement. Using positive politeness as an example, a female instructor may remark, "You lovely lad in the backside, read the material please." As a result of the feedback, this pupil has a good attitude toward the teacher. The teacher complimented the boy by saying "handsome," which made him and his friend giggle. Following that, the chosen pupil smiled and responded, "Yes mam, with pleasure." When the teacher asks, "Could you read the first paragraph?" it's a very other story. Although the pupils respond with a simple "yes sir," their demeanor is noticeably passive. There are no pleasant facial expressions such as a grin or a chuckle can be seen. Another instance is when a teacher motivates his or her students. "Good morning children, such a wonderful day to begin the meeting." and "happy to see you on this meeting," the teacher says in the data. When all of the kids have responded in unison and smiled at the instructor, it's time to move on. During the incentive portion, students pay close attention and maintain a cheerful demeanor. It appears that pleasant contact was fostered in the classroom.

\section{CONCLUSION}

Since the previous studies showed that different genders have often provided different expression on daily interaction, as the support, this study also found the same result in English language teaching context. Moreover, the differentiation of those expressions has influenced the variety of politeness strategies applied by male and female teachers. Each strategy run the student-teacher interaction in different ways. But, it is only positive politeness that is indicated as a politeness strategy maximized the student-teacher interaction the most.

In conclusion, when comparing the expression of politeness among male and female teachers, it proves that different gender teachers prefer different politeness strategies to be conducted during the teaching and learning process. The male teacher tends to use bald on record since the teacher does not like to talk too much. While the female teacher often uses positive politeness strategy since the teacher want to keep her students' positive face.

Furthermore, connecting the politeness strategy to student-teacher classroom interaction, the result show that different politeness strategy influences the student attitude toward the teacher. Using the appropriate politeness strategy will affect the development of student-teacher interaction. This study found positive politeness strategy used by female teacher

133 | IJET| Volume. 10, Issue 2. December 2021

Copyright 2021 Riyan Febriansyah, Ahmad Munir, Syafi'ul Anam, and Slamet Setiawan are licensed under Creative Commons Atrribution-ShareAlike 4.0 International License. 
build up more students' willingness to communicate. As the effect, the student-teacher interaction in female teacher classroom are investigated as more communicative.

It is always imperfectness in every human product, including this research. In order to persuade another researchers to fulfill the study under the umbrella of politeness strategies in English language teaching, there are still deeper topic that can be investigated such how the teacher's experiences (fresh graduate teacher \& senior teachers) may influence their politeness strategy, or how blended classroom may also influence teachers' politeness strategy.

\section{REFERENCES}

Aulia, N. (2017). Politeness Strategies in EFL Classroom: Building Positive Values in Students. Advances in Social Science, Education and Humanities Research, 10(9).

Boufranch, \& Conejos. (2003). Teaching Linguistic Politeness: A Methodological Proposal. International Review of Applied Linguistics in Language Teaching, 4(1), 1-22.

Brown, \& Levinson. (1987). Politeness: Some Universals in Language Use. Cambridge University Press.

Coates, J. (2004). Women, Men and Language. Pearson Education Limited.

Creswell, J. (2007). Qualitative Enquiry \& Research Design, Choosing among Five Approach. $\begin{array}{llll}\text { Australasian Emergency Nursing } & 11(2),\end{array}$ https://doi.org/10.1016/j.aenj.2008.02.005

Davies, A., \& Elder, C. (2004). The Handbook of Applied Linguistics Blackwell Publishing Blackwell Handbooks in Linguistics. Blackwell Handbooks in Linguistics, 17, 866. https://doi.org/10.1002/9780470757000.ch7

Eelen. (2008). A Critique of Politeness Theories. St. Jerome Publishing.

Eliasoph, N. (2003). Politeness, power, and women's language: Rethinking study in language and gender. Berkeley Journal of Sociology, 32, 79-103.

Hanik, Widiyatmike, \& Mursalim. (2019). Gender Representation and Language Politeness in Speech Events of Senior High School Students and Vocational High School Student in Samarinda: A Pragmatic Study. Advances in Social Science, Education and Humanities Research Journal, 43(2), 104-106.

Jiang. (2010). A Case Study of Teacher's Politeness in EFL Class. Journal of Language Teaching and Research, 1(5), 651-655.

Kasper. (2005). Linguistic politeness: Current research issues. Longman Linguistics Press. Lakoff, \& Ide. (2005). Broadening The Horizon of Linguistic Politeness. John Benjamins Publishing Company.

Leech, G. (1983). Principles of Pragmatics. Longman Linguistics Press.

Mahmud, M. (2019). The Use of Politeness Strategies in The Classroom Context by English University Students. Indonesian Journal of Applied Linguistics, 8(3), 597. 
https://doi.org/10.17509/ijal.v8i3.15258

Makarova, V., \& Pourmohammadi, E. (2019). Gender Factor in The Expression of Politeness in Farsi. Journal of Gender Studies, 1-13. https://doi.org/10.1080/09589236.2019.1604327

Maxcy, \& Spencer. (2003). Pragmatic threads in mixed methods research in the social sciences: The search for multiple modes of inquiry and the end of the philosophy of formalism. Handbook of Mixed Methods in Social and Behavioral Research, 51-89.

Murphey, T. (2001). Exploring conversational shadowing. Language Teaching Research, 5(2), $128-155$.

Peng, L. (2012). Research on College Teachers' Politeness. Journal of Language Teaching and Research, 3(2).

Rajesh, S., \& Udgaonkar, S. (2018). Influence of Gender and Age of Teachers on Teaching: Students Perspective. International Journal of Current Microbiology and Applied Sciences, 7(1), 2436-2441. https://doi.org/10.20546/ijcmas.2018.701.293

Ryabova, M. (2015). Politeness Strategy in Everyday Communication. Procedia - Social and Behavioral Sciences, 206, 90-95. https://doi.org/10.1016/j.sbspro.2015.10.033

Sulu, A. (2015). Teacher's Politeness in EFL Class. International Online Journal of Education and Teaching, 2(4), 216-221.

Watts, R. J. (2003). Politeness. In Key topics in sociolinguistics CN - P40.5.E75 W38 2003. Cambridge University Press. 